\title{
IMPACT OF INSTITUTIONS ON ECONOMIC GROWTH ACROSS OECD COUNTRIES
}

\section{Óscar Afonso ${ }^{a}$ iD, Inês Almeida ${ }^{a}$ Natércia Fortuna ${ }^{a}$}

\begin{abstract}
This paper provides empirical evidence in support of the view that quality of institutions is an important determinant of medium and long-term growth in OECD countries. Regarding the methodology, a panel data analysis with two-stage least squares (2SLS) estimation will be used to account for the endogeneity of the institutional variable. Besides institutional quality, we also consider other relevant determinants of potential growth such as the initial level of GDP per capita, public debt, and structural variables typically referred to in economic growth theory. Our estimation results show a positive impact of institutions on subsequent economic growth: an increase in 1 point in institutional quality leads to an estimated increase of 16.88 percentage points in potential GDP per capita growth, in the case of high-debt countries. With this, we notice a particular relevance of institutions in countries with high levels of debt. Therefore, our findings support the necessary attention to the institutional tissue of societies since improvements in institutional quality can subsequently improve economic growth.
\end{abstract}

Keywords: Economic growth, institutions, panel data, TSLS, endogeneity

JEL Classification: C23, O10, O43

\section{Introduction}

For a long time, economic growth explanation relied mainly on factors such as the augmentation of physical and human capital, and technical progress. However, such variables could not explain economic growth thoroughly, which led to the search for other determinants. Evidence has been increasingly pointing out towards institutions as a decisive economic growth factor (Valeriani and Peluso, 2011).

The literature concerning institutions and their effects is vast, quite heterogeneous, with a broad range of definitions and measures. ${ }^{1}$ One typical way to categorize institutions

a Universidade do Porto, Faculdade de Economia, CEF.UP, Portugal; CEF.UP is financed by Portuguese public funds through FCT - Fundação para a Ciência e a Tecnologia, I.P., in the framework of the project with references UIDB/04105/2020 and UIDP/04105/2020.

Email: oafonso@fep.up.pt

1 The most seminal references for the paper are presented here. However, the reader should be informed that the authors have an extensive review of the available literature upon request. 
is the institutional framework coming from North (1991). There can be a further distinction between economic, political and cultural institutions (Porta et al., 1999; Kuncic, 2012).

Evidence shows that the relevance of institutions differs according to context, namely the level of a country's development. They seem to be more crucial for developing countries (Glaeser et al., 2004). For example, when comparing differences in economic institutions, the main conclusion is that country institutions became more market-friendly in the 1980s and 1990s, reducing institutional differences (Freeman, 2002). Some similarities are therefore expected in the institutional quality of OECD countries.

Initially, empirical studies indicated that redistributive activities were more likely to occur with institutions that valued productive activity less, limiting investment and growth (Ali, 2003). Similarly, when property rights are poorly defined, powerful interest groups usually pursue unproductive activities, expropriating rents (Tornell and Lane, 1999), leaving developing countries with little chance of growth. In our opinion, it is also crucial to understand whether institutions are relevant for developed countries, given their potential for transmission.

With much of the literature studying the impact of institutional differences on economic growth being done on global samples or developing countries, there is therefore a lack of studies for the case of developed countries (Eicher and Röhn, 2007). One exception is Masuch et al. (2016), who consider the group of European countries to study the impact of institutions on growth, using the World Governance Indicators (WGIs) as a measure of institutional quality. Since their study covers only a small sample of developed countries, the research should be expanded to draw more robust conclusions. Thus, there seems to be a gap in the literature measuring the impact of institutions in developed countries, taking OECD countries among other variables. It is of interest to understand whether institutions generate disparities in this set of countries and whether they affect economic growth.

Our research questions are: What is the impact of institutions on economic growth in OECD countries? What is the relevance of institutions for developed countries?

To answer them, we use panel data and estimate the model using the two-stage least squares (2SLS) to account for the endogeneity of the institutional variable. The institutions' endogeneity to macroeconomic outcomes also arises because these variables have been generally measured ex-post. We can also argue that institutions might depend on the level of output per worker in an economy. In this paper, we use legal origin dummies as instruments for institutional delivery, following Porta et al. (1999) and other robustness checks, i.e., different measures of institutions and the inclusion of other structural control variables. By using legal origins, we test the hierarchy of institutions hypothesis (Acemoglu et al., 2004). While economic institutions affect economic performance, they are themselves both directly and indirectly influenced by political institutions. 
Our approach is similar to that of Eicher and Leukert (2009), who use a set of political institutions as instruments for economic institutions. However, our instruments do not suffer from an ex-post measurement bias, as they refer to the legal origins.

The dependent variable will measure the average potential growth of GDP per capita (GDPpc) over 3, 5, 10 and 15 years to see how the initial conditions affect economic growth. Using data from 1995 to 2021 for potential GDPpc, calculating the average over 15 years leaves us with a small sample. Two models are then estimated: a base model, considering the institutional variables, the initial level of GDPpc, and public debt; and a final model to which we add structural variables typically referred to in the economic growth literature. The focus will be on formal and economic institutions, using as proxy the WGIs, which enter our growth regression as an institutional quality variable.

The conclusions support the idea that institutions are important for medium and long-term economic growth in developed countries. They are vital in countries with high debt, as they can cushion the damaging effects of high debt on economic growth. Moreover, institutions maintain their meaning and signal when considering other relevant macroeconomic variables, revealing their importance in explaining economic growth.

After this brief introduction, the paper will be structured as follows. In Section 2, we discuss the data and methodology used. In Section 3, we present the empirical model and discuss the results. Finally, in Section 4, the main conclusions and limitations are presented.

\section{Data Analysis and Methodology}

Institutions are an important factor to consider when studying economic growth (Porta et al., 1999; Rodrik, 2003 and 2004; Nugroho et al., 2019). Institutions are a concept that must be contextualized: they are quite dependent on the level of the country's development (Rodrik, 2003). The sample used will cover the following 36 OECD countries: Australia, Canada, Ireland, the United Kingdom, New Zealand, the United States of America, Belgium, Chile, France, Greece, Israel, Italy, Luxembourg, Mexico, the Netherlands, Poland, Portugal, Spain, Turkey, Austria, the Czech Republic, Germany, Hungary, Japan, Korea, Slovakia, Slovenia, Switzerland, Denmark, Finland, Iceland, Norway, Sweden, Estonia, Latvia and Lithuania. The data frequency is yearly. For the potential GDPpc, data are available from 1995 to 2021, while the independent variables are from 1996 to 2018. Despite these time frames, when considering the dependent variable, the averaging potential GDPpc growth over 15 years, our sample is from 1995 to 2006. The data are collected from the World Bank and the OECD datasets. The choice of variables takes into account the literature and our objectives. Below we describe the variables used. 


\section{Potential GDP per capita}

The dependent variable measures the growth rate of the potential gross domestic product per capita (GDPpc) in PPP. It is defined by Chalaux and Guillemette (2019) as the level of production that can be achieved in a medium and long-term economy while keeping the inflation rate constant. Potential output depends on the capital stock, the potential labour force, the non-accelerating inflation rate of unemployment, and the level of labour efficiency. Several factors affect the level of potential output and its growth rate, including institutional and structural economic policies (European Central Bank, 2011). Potential output assumes that all inputs are attributed to their most productive uses (World Bank Group, 2018). Potential GDP is used to check how initial conditions in variables, such as institutions and debt, affect long-term economic growth. We use 3, 5, 10 and 15 years of average potential GDPpc growth to verify how the different terms affect the results of the estimate. The value of potential purchasing power GDP volume is obtained from the OECD database, ${ }^{2}$ using data from 1995 to 2021. From the total population, obtained from the World Bank, ${ }^{3}$ we calculate the potential GDPpc. To obtain the 15 -year average, we add the next 15 years of potential GDPpc values in each initial year and then divide it by 15 .

\section{GDP per capita}

GDPpc at constant 2015 prices (in dollars) in PPP is used to measure the initial level. The neoclassical model predicts a negative relationship between the initial level of GDP and economic growth (Barro, 1996). It is included to measure the convergence effect, which means that countries with an initially low GDPpc should have higher economic growth rates. Data for GDPpc are available in the OECD database, ${ }^{4}$ and show an increasing trend from 1996 to 2006. The OECD can be considered a "convergence club" as member countries share the same practices in various fields, leading to similar policies and results, reducing differences in production levels. However, the data show that there has been a convergence in growth rates rather than convergence in GDPpc levels (Vanston, 2006).

\section{Institutions}

We will use an aggregate institutional quality measure from the WGI database developed by Kaufmann, Kraay and Mastruzzi for the World Bank. It includes six governance

2 https://stats.oecd.org/index.aspx, (March 2020).

3 https://data.worldbank.org/indicator/SP.POP.TOTL?end=2019\&start=1997, (September 2020).

4 https://stats.oecd.org/Index.aspx?DataSetCode=PDB_LV\# (March 2020). 
indicators: corruption, government effectiveness, political stability and absence of violence, regulatory quality, rule of law, and voice and accountability (Table 1). Another division can be made by dividing the six indicators into two groups, one considering the quality of a country's democratic process with voice and responsibility and indicators of political stability and absence of violence, and the other group capturing the quality of economic and administrative institutions with the remaining indicators (Helliwell et al., 2014). WGIs are available for over 200 countries and are based on several variables that capture governance perceptions obtained from non-governmental organizations and public and private respondents (Kraay et al., 2010). The estimation of each indicator follows a normal random variable, ranging from -2.5 to 2.5 , with higher scores meaning better institutional results (Apaza, 2009). The choice of this aggregate measure is based on its proven accuracy, free availability, and for being a complete indicator with several institutional measures (Fuentelsaz et al., 2019; Thomas, 2010). Pasimeni and Pasimeni (2016) also recognize WGIs as an excellent source to operationalize an institutional analysis of the economic growth process. Despite these advantages, the WGIs are also associated with some criticism, namely for being a perception-based indicator.

\section{Table 1: Definition of WGIs}

\begin{tabular}{l|l}
\hline WGI & \multicolumn{1}{c}{ Definition } \\
\hline $\begin{array}{l}\text { Control } \\
\text { of corruption (CC) }\end{array}$ & $\begin{array}{l}\text { The extent to which public power is exercised for private gain and "capture" } \\
\text { of the state by elites and private interests. }\end{array}$ \\
\hline $\begin{array}{l}\text { Government } \\
\text { effectiveness (GE) }\end{array}$ & $\begin{array}{l}\text { The quality of public services, the quality of the civil service and the degree } \\
\text { of its independence from political pressures, the quality of policy formulation } \\
\text { and implementation, and the credibility of the government's commitment } \\
\text { to such policies. }\end{array}$ \\
\hline $\begin{array}{l}\text { Political stability } \\
\text { and absence } \\
\text { of violence (PV) }\end{array}$ & $\begin{array}{l}\text { Perceptions of the likelihood that the government will be destabilized } \\
\text { or overthrown by unconstitutional or violent means, including political } \\
\text { violence or terrorism. }\end{array}$ \\
$\begin{array}{l}\text { Regulatory } \\
\text { quality (RQ) }\end{array}$ & $\begin{array}{l}\text { The government can formulate and implement sound policies and regulations, } \\
\text { which permit and promote private sector development. }\end{array}$ \\
\hline $\begin{array}{l}\text { Roice and } \\
\text { accountability (VA) }\end{array}$ & $\begin{array}{l}\text { The extent to which a country's citizens can select their government and } \\
\text { freedom of expression, freedom of association and free media. }\end{array}$ \\
\hline $\begin{array}{l}\text { The extent to which agents have confidence in and abide by society's rules, } \\
\text { particularly the quality of contract enforcement, the police and the courts, } \\
\text { and the likelihood of crime and violence. }\end{array}$
\end{tabular}

Source: Kraay, Kaufmann, Mastruzzi (2010) 
For each of the WGIs, we apply a 3-year centred moving average to include as many data as possible, since until 2002 data are only available on a semi-annual basis (data for the years 1997, 1999 and 2001 are missing), obtaining data from 1998 onwards. Thus, to build the WGI series, we have averaged the six OECD country indicators. The institutional quality as proxied by the WGI shows an increase until 2003, reflecting possible improvements in institutions, followed by a decrease until 2006. Overall, for the period between 1998 and 2006, institutional quality increased for OECD countries.

\section{Public debt}

Debt is measured by general government debt as a percentage of GDP (OECD, 2020). Debt can be used to finance productive investments, in which case the relationship with economic growth is positive, or unproductive expenditures, in which case the relationship is negative. It is more likely to have an impact on economic growth when its levels are high: in that case, interest rates may increase and penalize private investment, or there may be an expected increase in future taxes, leading to lower economic growth (Chalk and Tanzi, 2002). High public debt may also affect economic growth through increased volatility (Panizza and Presbitero, 2013). Public debt is related negatively and non-linearly to potential economic growth, with a critical threshold beyond which debt is detrimental to economic growth (Mencinger et al., 2015). The threshold considered for the negative impact on growth can be set at $60 \%$ (Égert, 2013). Similarly, Masuch et al. (2016) use the Maastricht threshold for European countries, which is also set at $60 \%$ of GDP. Since the OECD has a representative sample of European countries, we chose this threshold.

The data are available in the OECD database ${ }^{5}$ and the resultant series is portrayed in Figure 1, for the years between 1996 and 2008.

The yearly average General government debt evolution for OECD shows a contained variation between 1996 and 2006, with debt values varying between 51\% and $58 \%$ of GDP, while never reaching the $60 \%$ threshold. After the crisis, the indebtedness increased, surpassing $60 \%$. For robustness matters, other variables are considered, namely structural ones such as Trade ( $\%$ of GDP), $T r$, Government expenditure on education (\% of GDP), GEEDU, General government final consumption expenditure (\% of GDP), GEXP, Gross capital formation (\% of GDP), GCF, Research and development (R\&D) expenditure (\% of GDP), $R D$, and Inflation (annual \%), $I N F$, all taken from the World Data Bank.

5 In https://data.oecd.org/gga/general-government-debt.htm, (March 2020). 


\section{Figure 1: Evolution of debt to GDP ratio for OECD}

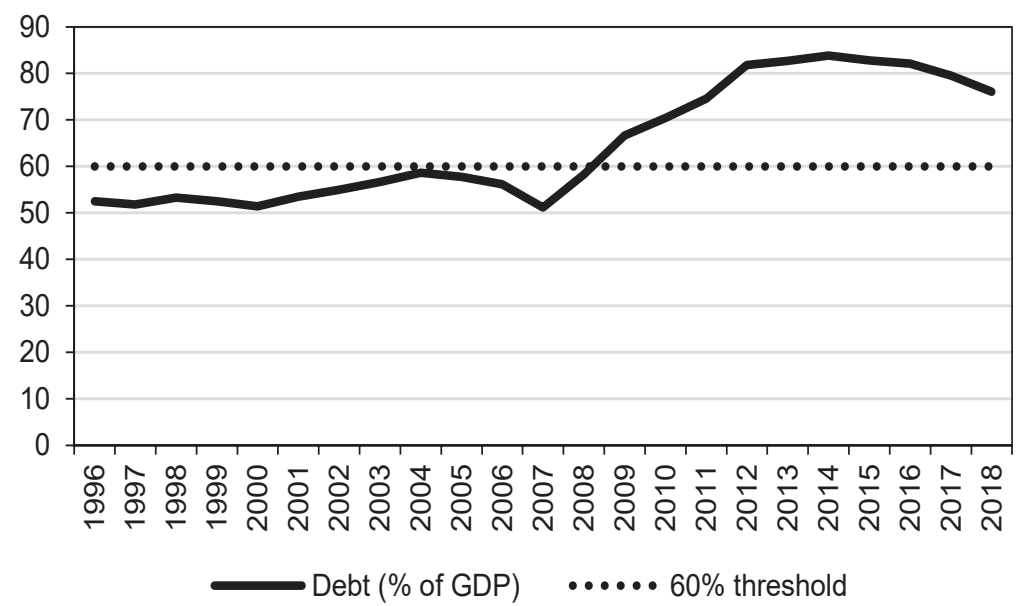

Source: Own calculations based on OECD database

\section{Trade}

Trade is measured as the share of exports and imports of goods and services in gross domestic product (World Bank, 2020). It affects economic growth through various channels: increased investment, technology diffusion, economies of scale and increased competition for companies with productivity gains (Singh, 2010). It is expected to affect economic growth positively through increased TFP productivity and to lead to low inflation (Bouis et al., 2011). The results show an increasing trend for Trade, from 1996 to $2018 .{ }^{6}$ The most noticeable increase happened after 2003 with , reaching approximately $100 \%$ of GDP by 2011.

\section{General government final consumption expenditure}

This variable includes all current government expenditures on goods and services (World Bank, 2020). It also includes most defence and national security spending, but excludes government military spending, which is part of government capital formation. After peaking at $19 \%$ of GDP in 2003, GEXP shows a downward trend until 2007. After that, it increased during the crisis, surpassing $20 \%$, and declined thereafter. ${ }^{7}$

6 https://data.worldbank.org/indicator/NE.TRD.GNFS.ZS?end=2019\&start=1996, (March 2020).

7 https://data.worldbank.org/indicator/NE.CON.GOVT.ZS?end=2019\&start=1996, (March 2020). 


\section{Government expenditure on education}

This variable is an indicator of human capital, measuring the flow that contributes to its improvement. It is useful for comparing education spending between countries and its evolution over time. Moreover, this variable measures the prioritization given to education, with high percentages of GDP suggesting a high prioritization of education (World Bank, 2020). The GEEDU shows an increasing trend from 1998 to 2003, reaching 10\% of GDP, and from 2003 there is a low variability until 2016, when it decreased suddenly.

\section{Gross capital formation}

It is a proxy for investment in physical capital and measures the flow that feeds the capital stock (World Bank, 2020). constitutes a crucial determinant of economic growth (Solow, 1956). The series shows a decrease in from 1998 to 2002, reaching the lowest value of approximately $23 \%$ of GDP in 2002 . After that, the values increased with gross capital formation reaching almost $26 \%$ of GDP by the year 2006, decreased in the crisis period to values close to $20 \%$, and then grew slightly. ${ }^{8}$

\section{R\&D expenditure}

This variable reflects the investment, both public and private, in research to increase knowledge and efficient use of existing resources (World Bank, 2020). It is typically related to creating new technologies and faster absorption of existing ones, with a higher level of R\&D expenditure allowing economic growth to be raised permanently (Bouis et al., 2011). It shows on average an increasing trend of 0.62 p.p. from 1996 to 2017 in OECD countries. ${ }^{9}$ The small percentages of public R\&D expenditure can result from a higher share of private $R \& D$, with the latter being responsible for most expenditure in this area in most OECD countries (Bassanini et al., 2001). Thus, public R\&D expenditure is expected to have smaller shares, with its investments being mainly directed to medical and defence research or education (Bassanini et al., 2001).

\section{Inflation}

Inflation is measured by the consumer price index, as described by the World Bank (2020). When inflation values are high, there is increased uncertainty and poor economic performance, reflecting the negative relationship between these two variables (Barro, 1996). The inflation rate is typically controlled via monetary policy and its control is one of the main objectives of Western economies. In an increasingly globalized world,

8 https://data.worldbank.org/indicator/NE.GDI.TOTL.ZS?end=2019\&start=1996 (March 2020).

9 https://data.worldbank.org/indicator/GB.XPD.RSDV.GD.ZS (March 2020). 
the inflation rate is also affected by this process. This is why, for example, Pain et al. (2008) found that inflation began to decline in the mid-1990s when the globalization process began to intensify. The downward trend is depicted in our series, as the trajectory of inflation shows a decline from about $9 \%$ to 3\% between 1996 and $2006 .{ }^{10}$

Table 2: Descriptive statistics of variables

\begin{tabular}{|c|c|c|c|c|c|c|}
\hline Variable & Unit & $\begin{array}{c}\begin{array}{c}\text { Number } \\
\text { of observa- } \\
\text { tions }\end{array} \\
\end{array}$ & Minimum & Mean & Maximum & $\begin{array}{l}\text { Standard } \\
\text { deviation }\end{array}$ \\
\hline $\begin{array}{l}\text { Average poten- } \\
\text { tial GDPpc } 15 \\
\text { years }\end{array}$ & $\begin{array}{l}\text { Real (purchas- } \\
\text { ing power) }\end{array}$ & 178 & $12,504.35$ & $34,570.86$ & $88,579.15$ & $13,271.30$ \\
\hline $\begin{array}{l}\text { Average poten- } \\
\text { tial GDPpc } 10 \\
\text { years }\end{array}$ & $\begin{array}{l}\text { Real (purchas- } \\
\text { ing power) }\end{array}$ & 178 & $8,185.65$ & $33,317.50$ & $87,608.00$ & $13,243.53$ \\
\hline $\begin{array}{l}\text { Average poten- } \\
\text { tial GDPpc } 5 \\
\text { years }\end{array}$ & $\begin{array}{l}\text { Real (purchas- } \\
\text { ing power) }\end{array}$ & 178 & $2,787.77$ & $31,949.99$ & $86,285.33$ & $13,243.14$ \\
\hline $\begin{array}{l}\text { Average } \\
\text { potential GDPpc } \\
3 \text { years }\end{array}$ & $\begin{array}{l}\text { Real (purchas- } \\
\text { ing power) }\end{array}$ & 178 & $4,646.28$ & $31,487.64$ & $85,952.69$ & $13,088.43$ \\
\hline GDP per capita & Real & 178 & $9,227.63$ & $34,227.84$ & $101,091.75$ & $15,402.72$ \\
\hline Institutions & Average & 178 & -0.33 & 1.19 & 1.96 & 0.54 \\
\hline $\begin{array}{l}\text { General } \\
\text { government } \\
\text { debt }\end{array}$ & $\%$ of GDP & 178 & 6.65 & 63.29 & 175.99 & 34.11 \\
\hline $\begin{array}{l}\text { Government } \\
\text { expenditure } \\
\text { on education } \\
\end{array}$ & $\%$ of GDP & 178 & 5.89 & 13.02 & 22.47 & 3.03 \\
\hline Trade & $\%$ of GDP & 178 & 18.35 & 81.58 & 320.60 & 43.95 \\
\hline $\begin{array}{l}\text { General } \\
\text { government } \\
\text { expenditure } \\
\end{array}$ & $\%$ of GDP & 178 & 8.12 & 18.51 & 26.91 & 3.82 \\
\hline $\begin{array}{l}\text { Gross capital } \\
\text { formation }\end{array}$ & $\%$ of GDP & 178 & 17.64 & 24.31 & 39.86 & 3.97 \\
\hline $\begin{array}{l}R \& D \\
\text { expenditure }\end{array}$ & $\%$ of GDP & 178 & 0.25 & 1.59 & 4.19 & 0.92 \\
\hline Inflation rate & $\begin{array}{l}\text { Consumer } \\
\text { price index } \\
\text { (annual \%) }\end{array}$ & 178 & -1.13 & 4.70 & 85.67 & 9.50 \\
\hline
\end{tabular}

Notes: (i) Data taken from OECD.stat and World Bank; (ii) data for potential GDP per capita are in current local currency; (iii) we apply the first difference natural logarithm to potential GDP per capita; (iv) the institutional variable was calculated as an average of the six WGIs; (v) the data are unbalanced. The frequency is yearly from 1996 to 2006 for the 36 countries.

Source: Own calculations based on OECD and World Bank

10 https://data.worldbank.org/indicator/FP.CPI.TOTL.ZG?end=2019\&start=1996 (March 2020). 
The descriptive statistics of each variable are presented in Table 2. Additionally, we have an instrument variable called Legal origins, which considers the deep cultural and legal characteristics behind the formal institutions. This approach is present in Masuch et al. (2016), Acemoglu et al. (2004), Eicher and Leukert (2009), and Acemoglu and Robinson (2010), where the deeper institutional determinants, typically constitutional institutions, are used as an instrument for the economic institutions. Following Porta et al. (1999), Legal origin will be a dummy variable used as an institutional variable instrument. Five different types of legal origin will be considered:

- English: Australia, Canada, Ireland, the United Kingdom, New Zealand, the United States of America;

- French: Belgium, Chile, France, Greece, Israel, Italy, Luxembourg, Mexico, the Netherlands, Poland, Portugal, Spain, Turkey;

- German: Austria, the Czech Republic, Germany, Hungary, Japan, Korea, Slovakia, Slovenia, Switzerland;

- Scandinavian: Denmark, Finland, Iceland, Norway, Sweden;

- Pan-European (PEU): Estonia, Latvia, Lithuania.

\section{Empirical Model and Results}

\subsection{Model specification}

As the intent is to study how initial conditions affect economic growth throughout time and across OECD countries, panel data are more appropriate. The first model will capture the links between the quality of institutions, the level of debt, the initial level of GDP per capita, and their impact on GDP per capita, assuming the following form:

$$
\Delta y_{i, t}=\beta_{0} y_{i, t}+\beta_{1} D_{i, t}+\beta_{2} I_{i, t}+\beta_{3} D_{i, t} \times I_{i, t}+\varepsilon_{i, t}, i=1, \ldots, 36 \text { and } t=1, \ldots, 12 .
$$

In (1), $\Delta y_{i, t}$ is the 15 -year average GDP per capita growth (log change of potential GDP per capita), at the time $t$ for the country $i ; y_{i, t}$ is the initial level of GDP per capita in constant prices (natural logarithm of GDP per capita level in PPP) at $t$ for $i$, representing the catching-up effect; $D_{i, t}$ is a dummy variable, at $t$ for $i$, which takes the value one if government debt is greater than $60 \%$ of GDP and 0 otherwise; $I_{i, t}$ measures the institutional quality at $t$ for $i$. 


\subsection{Interpretation of results}

Three possible models can be used: pooled ordinary least squares (OLS), fixed-effects (FEM), or random-effects (REM). The fixed-effect F-test allows us to reject the null hypothesis, meaning that period fixed-effects is a more suitable model than the pooled OLS (Table 3). In turn, applying the Hausman test, in which the null hypothesis is rejected, confirms that FEM is the most appropriate model to use. Consequently, we select the FEM.

Considering the concerns about the endogeneity of the institutional variable, we use two-stage least squares to estimate the model. In 2SLS, one must find valid instrumental variables that fulfil two criteria: (i) the instruments must be uncorrelated with the error term in the initial equation, and (ii) the instruments are strongly correlated with the endogenous regressor (Eicher and Leukert, 2009).

As the name indicates, this method has two stages. In the first stage, the endogenous variables become the dependent variable, which is regressed on all the exogenous and instrument variables, creating the fitted values series. Then, in the second stage, the estimated series obtained from this regression replaces the original series of the endogenous variable.

In the first stage, to test whether the two variables, $I$ and $D \times I$ are endogenous, we perform the Wu-Hausman test, the results of which are reflected in Table 4. Since we reject the null hypothesis, we can conclude that the variables are endogenous not only jointly but also individually in the case of the variable $I$. Additionally, we can also verify whether the instruments used are relevant, using the Wald F-statistic value reported in Table 3 of the first stage. The values confirm that the instruments used are relevant.

In the baseline regression, institutions appear both alone and interacting with the debt dummy variable. Since Legal origins is a valid instrument for institutions, using Legal origins interacted with the debt dummy can also be considered valid as an instrument for institutions interacted with the debt dummy variable (Masuch et al., 2016).

Consequently, there will be two reduced-form equations to estimate in the first step: one in which the dependent variable is $I$, as the institutional variable; and the other one which has the interaction term, $D \times I$, as the dependent variable. The instrument chosen for the institutional quality is Legal origin (LO), as done by Masuch et al. (2016). The LO variable is disaggregated into its five possibilities: English, French, German, Scandinavian and Pan-European (PEU) denoted respectively in the equation as eng, fr, ger, sca, and peu. The variable English was omitted to avoid perfect multicollinearity. The final sample used for the three models is 178 observations for 36 countries between 1996 and 2006.

The two reduced equations are:

$$
\begin{aligned}
& I_{c, t}=\alpha_{0}+\alpha_{1} y 1_{c, t}+\alpha_{1} D_{c, t}+\alpha_{2} f r_{c, t}+\alpha_{3} g e r_{c, t}+\alpha_{4} s c a_{c, t}+\alpha_{5} p e u_{c, t}+\alpha_{6} D_{c, t} \times f r_{c, t}+ \\
& +\alpha_{7} D_{c, t} \times g e r_{c, t}+\alpha_{8} D_{c, t} \times s c a_{c, t}+\alpha_{9} D_{c, t} \times p e u_{c, t}+\varepsilon_{c}
\end{aligned}
$$




$$
\begin{aligned}
& D_{c, t} I_{c, t}=\delta_{0}+\delta_{1} y 2_{c, t}+\delta_{1} D_{c, t}+\delta_{2} f r_{c, t}+\delta_{3} g e r_{c, t}+\delta_{4} s c a_{c, t}+\delta_{5} \mathrm{peu}_{c, t}+ \\
& \delta_{6} D_{c, t} \times f r_{c, t}+\delta_{7} D_{c, t} \times g e r_{c, t}+\delta_{8} D_{c, t} \times s c a_{c, t}+\delta_{9} D_{c, t} \times p e u_{c, t}+\varepsilon_{c, t}
\end{aligned}
$$

The estimation results are presented in Table 3.

\begin{tabular}{|c|c|c|c|c|}
\hline \multirow[b]{2}{*}{ Explanatory variables } & \multicolumn{2}{|c|}{$I$} & \multicolumn{2}{|c|}{$D \times I$} \\
\hline & Pooled OLS & $\begin{array}{c}\text { Period fixed- } \\
\text { effect }\end{array}$ & Pooled OLS & $\begin{array}{l}\text { Period fixed- } \\
\text { effect }\end{array}$ \\
\hline $\ln (G D P p c)$ & $\begin{array}{l}0.7948^{* * * *} \\
(0.044)\end{array}$ & $\begin{array}{l}0.8845^{* * *} \\
(0.035)\end{array}$ & $\begin{array}{c}0.2173^{* * *} \\
(0.034)\end{array}$ & $\begin{array}{l}0.2394^{* * *} \\
(0.030)\end{array}$ \\
\hline French & $\begin{array}{c}-0.4764^{* * *} \\
(0.066)\end{array}$ & $\begin{array}{c}-0.3858^{* * *} \\
(0.048)\end{array}$ & $\begin{array}{l}0.0027 \\
(0.027)\end{array}$ & $\begin{array}{l}0.0332 \\
(0.026)\end{array}$ \\
\hline German & $\begin{array}{c}-0.2482^{* * *} \\
(0.024)\end{array}$ & $\begin{array}{c}-0.1833^{* * * *} \\
(0.022)\end{array}$ & $\begin{array}{l}0.0591^{* *} \\
(0.023)\end{array}$ & $\begin{array}{l}0.0904^{* * *} \\
(0.020)\end{array}$ \\
\hline Scandinavian & $\begin{array}{l}0.1146^{* * *} \\
(0.024)\end{array}$ & $\begin{array}{l}0.1786^{* * *} \\
(0.020)\end{array}$ & $\begin{array}{c}-0.0263^{* * * *} \\
(0.010)\end{array}$ & $\begin{array}{l}0.0026 \\
(0.009)\end{array}$ \\
\hline Pan - European & $\begin{array}{c}-0.2144^{* * *} \\
(0.036)\end{array}$ & $\begin{array}{c}-0.0864^{* * *} \\
(0.031)\end{array}$ & $\begin{array}{l}0.1546^{* * *} \\
(0.023)\end{array}$ & $\begin{array}{l}0.2081^{* * * *} \\
(0.021)\end{array}$ \\
\hline Debtover60 & $\begin{array}{c}-0.1751^{* * *} \\
(0.023)\end{array}$ & $\begin{array}{c}-0.0806^{* * * *} \\
(0.020)\end{array}$ & $\begin{array}{l}1.4545^{* * *} \\
(0.014)\end{array}$ & $\begin{array}{l}1.5055^{* * *} \\
(0.012)\end{array}$ \\
\hline Debtover60 × French & $\begin{array}{l}0.2225^{* * *} \\
(0.079)\end{array}$ & $\begin{array}{l}0.1340^{* *} \\
(0.062)\end{array}$ & $\begin{array}{c}-0.4247^{* * * *} \\
(0.037)\end{array}$ & $\begin{array}{c}-0.4565^{* * *} \\
(0.034)\end{array}$ \\
\hline Debtover60 × German & $\begin{array}{l}0.1999^{* * * *} \\
(0.031)\end{array}$ & $\begin{array}{l}0.1527^{* * *} \\
(0.029)\end{array}$ & $\begin{array}{c}-0.2652^{* * *} \\
(0.037)\end{array}$ & $\begin{array}{c}-0.2761^{* * *} \\
(0.034)\end{array}$ \\
\hline Debtover $60 \times$ Scandinavian & $\begin{array}{l}0.2185^{* * * *} \\
(0.045)\end{array}$ & $\begin{array}{l}0.1099 * * * \\
(0.041)\end{array}$ & $\begin{array}{l}0.3080^{* * *} \\
(0.023)\end{array}$ & $\begin{array}{l}0.2555^{* * *} \\
(0.020)\end{array}$ \\
\hline Sample size & 178 & 178 & 178 & 178 \\
\hline Adjusted R-squared & 0.7309 & 0.7705 & 0.8844 & 0.9023 \\
\hline Wald F-statistic & $\begin{array}{c}194.1593 \\
(0.000)\end{array}$ & $\begin{array}{l}75.091 \\
(0.000)\end{array}$ & $\begin{array}{c}629.7694 \\
(0.000)\end{array}$ & $\begin{array}{c}204.8307 \\
(0.000)\end{array}$ \\
\hline Period effect F-statistic & - & $\begin{array}{l}7.7920 \\
(0.000)\end{array}$ & - & $\begin{array}{l}2.5331 \\
(0.000)\end{array}$ \\
\hline
\end{tabular}

Table 3: Estimation results for first stage of 2SLS

Notes: (i) In parentheses and under each estimate, there are the corresponding robust standard errors, using the cross-section SUR (panel-corrected standard errors) method; (ii) symbols $* * *, * *, *$ indicate the level of significance at $1 \%, 5 \%$ and $10 \%$; (iii) the Wald F-statistic tests the global significance of the regression, where the value inside parentheses gives us the $p$-value; (iv) in the F-test, the value in parentheses gives us the $p$-value

Source: Own calculations 


\begin{tabular}{l|c|c|c|c}
\hline \multicolumn{5}{c}{ Average potential per capita growth } \\
\hline & 3-years & 5-years & 10-years & 15-years \\
\hline F-statistic for Institutions & 6.8182 & 5.5730 & 1.6319 & 5.4135 \\
and Institutions Debtover60 & $(0.002)$ & $(0.005)$ & $(0.200)$ & $(0.006)$ \\
\hline & -3.6538 & -3.2937 & -1.8030 & -3.0888 \\
t-statistic for Institutions & $(0.000)$ & $(0.001)$ & $(0.074)$ & $(0.003)$ \\
\hline
\end{tabular}

Note: The respective $p$-value is shown in parentheses under the value of each statistic.

Source: Own calculations

After estimating the two instrumental equations, we obtain the fitted values of the two dependent variables that will be later inserted in the original equation. In the second step, the fitted values of $I_{i, t}$ and $D_{i, t} \times I_{i, t}$ are plugged in the original equation (1). These two variables will be addressed in the next regressions as Institutions and Institutions $\widehat{\times}$ Debtover 60 .

\subsection{Baseline and final models}

In the second step of 2SLS, we conclude that fixed-effects are also the appropriate model for both dimensions.

Since our focus is to study the impact of institutions on growth, we introduce the baseline model, which contains as regressors the initial GDPpc level, $\ln (G D P p c)$, the institutional quality (Institutions), the Debtover60 dummy, and the interaction of the institutional variable with the Debtover60 dummy (Institutions $\widehat{\times}$ Debtover60), allowing to capture the impact differences of institutions in countries with debt greater than $60 \%$ of GDP against those that have less or equal to $60 \%$. Next, adding all the structural variables referred to in the literature as determinants of economic growth, we want to test whether institutions' explanatory power holds. Those variables are Government expenditure on education in \% of GDP (GEEDU), Trade in \% of GDP (Tr), General government final consumption expenditure in \% of GDP (GEXP), Gross capital formation in \% of GDP $(G C F), \mathrm{R} \& \mathrm{D}$ expenditure in \% of GDP $(R D)$ and Inflation $(I N F)$. This so-called final model is used to make a parallel analysis for different time spans of potential GDPpc growth for 3, 5, 10 and 15-years. To verify whether the variables added to the baseline model improve the model, we perform a Wald F-test for every growth span. We reject the null hypothesis at $1 \%$, proving that the final model holds better explanatory power than the baseline model. Thus, the analysis is done for the final model. ${ }^{11}$

The results are presented in Table 5.

11 The OECD includes many countries that changed their institutions enormously during the referred period and were subject to relatively strong economic convergence. We estimated the same models for the following group of countries, CEE and PIIGS, and similar results were obtained. 
Table 5: Estimation output of second step of equation (1)

\begin{tabular}{|c|c|c|c|}
\hline \multirow{3}{*}{ Explanatory variables } & \multicolumn{3}{|c|}{ 15-year average potential GDP per capita growth $[1996,2006]$} \\
\hline & \multirow{2}{*}{$\begin{array}{l}\text { Pooled OLS } \\
\text { final }\end{array}$} & \multicolumn{2}{|c|}{ Country and period fixed-effects } \\
\hline & & Baseline & Final \\
\hline $\ln (G D P p c)$ & $\begin{array}{l}-2.7894^{* * *} \\
(0.180)\end{array}$ & $\begin{array}{l}-20.5595^{* * *} \\
(5.568)\end{array}$ & $\begin{array}{l}-18.2062^{* * *} \\
(5.325)\end{array}$ \\
\hline Institutions & $\begin{array}{l}0.6080^{* * *} \\
(0.171)\end{array}$ & $\begin{array}{l}16.8572^{* * *} \\
(0.056)\end{array}$ & $\begin{array}{l}16.2291^{* * *} \\
(5.332)\end{array}$ \\
\hline Debtover60 & $\begin{array}{l}-0.9677^{* * *} \\
(0.225)\end{array}$ & $\begin{array}{l}-1.4532^{* *} \\
(0.586)\end{array}$ & $\begin{array}{l}-1.5556^{* *} \\
(0.614)\end{array}$ \\
\hline Institutions $\widehat{x D e b t o v e r 60}$ & $\begin{array}{l}0.5478^{* * *} \\
(0.150)\end{array}$ & $\begin{array}{l}0.5166^{* *} \\
(0.255)\end{array}$ & $\begin{array}{l}0.6525^{* *} \\
(0.311)\end{array}$ \\
\hline $\ln (G E E D U)$ & $\begin{array}{l}1.3067^{* * *} \\
(0.104)\end{array}$ & - & $\begin{array}{l}2.2272^{* * *} \\
(0.800)\end{array}$ \\
\hline $\ln (T r)$ & $\begin{array}{l}1.1467^{* * *} \\
(0.047)\end{array}$ & - & $\begin{array}{l}2.8390 * * * \\
(0.873) \\
\end{array}$ \\
\hline $\ln ($ GEXP) & $\begin{array}{c}-0.0103 \\
(0.183) \\
\end{array}$ & - & $\begin{array}{l}5.3745^{* * *} \\
(1.209) \\
\end{array}$ \\
\hline GCF & $\begin{array}{l}-0.0039 \\
(0.005)\end{array}$ & - & $\begin{array}{l}0.0220 \\
(0.027)\end{array}$ \\
\hline$R D$ & $\begin{array}{l}-0.0912^{* * *} \\
(0.027)\end{array}$ & - & $\begin{array}{l}0.0952 \\
(0.268)\end{array}$ \\
\hline INF & $\begin{array}{l}0.0142 \\
(0.009) \\
\end{array}$ & - & $\begin{array}{l}0.0380 \\
(0.027) \\
\end{array}$ \\
\hline Sample size & 178 & 178 & 178 \\
\hline Adjusted R-squared & 0.9538 & 0.8311 & 0.8700 \\
\hline Wald F-statistic & $\begin{array}{c}1840.302 \\
(0.000)\end{array}$ & $\begin{array}{c}2160.614 \\
(0.000)\end{array}$ & $\begin{array}{c}1371.901 \\
(0.000)\end{array}$ \\
\hline $\begin{array}{l}\text { Country and period fixed- } \\
\text { effects F-test }\end{array}$ & - & $\begin{array}{l}8.1714 \\
(0.000)\end{array}$ & $\begin{array}{l}6.9769 \\
(0.000)\end{array}$ \\
\hline
\end{tabular}

Notes: See Table 3.

Source: Own calculations

The variable $\ln (G D P p c)$, which represents the catching-up effect, i.e., the impact of the initial level of GDPpc on economic growth, is significant at a $1 \%$ level and affects growth negatively. That result is expected since higher initial GDPpc levels are linked with lower economic growth, known as conditional convergence. In our case, an estimated increase of $1 \%$ in the initial level of GDPpc results in a decrease of 0.18 p.p. in potential GDP growth, ceteris paribus (c.p.). 
The institutional quality variable, (Institutions), is significant at $1 \%$. The results hold in both baseline and final models, with institutions holding their significance even when adding other variables. The debt dummy interacted with the institutional variable, also significant and with an estimated positive coefficient, depicts the positive effect that sound institutions can have on growth in high debt. In our case, an estimated increase of 1 point in institutional quality is associated with an increase of 16.88 p.p. in potential GDP growth in high-debt countries, and of 16.23 p.p. in the case of low-debt countries, c.p. That is, a country with good institutions can accommodate the negative impact of high debt on growth. In turn, if a country has low institutional quality, high debt will impact on economic growth negatively: countries with high debt levels and low institutional quality can benefit if they improve their institutional quality.

The debt dummy variable is significant at $5 \%$ and has a negative estimated impact, indicating the detrimental effect of high government debt on growth. This estimate gives us the difference between the potential GDPpc growth between high- and low-debt countries when institutional quality assumes zero value. It is estimated that the potential GDPpc growth is $1.56 \%$ inferior in the case of high debt, relatively to low debt, c.p. Hence, high debt is more detrimental to potential GDPpc growth by $1.56 \%$ than low debt. High debt is detrimental to economic growth since it raises interest rates, crowds out private investment, and leads to higher expected future taxation (Mencinger et al., 2015).

Government expenditure on education is significant at $1 \%$, and the estimated effect is positive, meaning that higher expenditure on education improves growth. This result is mostly referred to in the literature since human capital improvements are typically linked with higher economic growth (Bassanini et al., 2001; Das and Quirk, 2016). In our case, an estimated increase of $1 \%$ in GEEDU leads to an increase of 0.022 p.p. on potential GDPpc growth in the final model, c.p. Moreover, due to the high social returns that education encompasses, it is a particularly relevant area for government investment.

Trade is also significant at $1 \%$ and has an estimated positive impact, showing the relevance of integration in international markets. Our results show that an estimated increase of $1 \%$ in is associated with an increase of 0.0284 p.p. in the estimated potential GDPpc growth, c.p. Trade is also recognized as a variable with a positive impact on economic growth through greater diffusion of knowledge and the possibility to create a more dynamic environment, also increasing the demand for better institutions (Alonso, 2011).

General government final consumption expenditure is significant at $1 \%$, showing the importance of government expenditure for collective consumption, providing public goods and services, and health care and housing provision. We estimate that an increase of $1 \%$ in GEXP is associated with an increase of 0.054 p.p. in potential GDPpc growth, c.p. 
Furthermore, the variables Gross capital formation, R\&D expenditure and Inflation are also featured, but not significant. The non-significance of inflation can be explained by the fact that 19 of the 36 countries considered are part of the European Monetary Union (EMU), whose main objective is to keep inflation constant and around 2\%; that is, monetary policy in the EMU acts to keep the inflation rate constant and, because of this, in the estimates it ends up having no impact on the potential GDPpc growth. In turn, the variables $G C F$ and $R D$ are not significant since both are related to investment. The literature refers to investment as one of the main channels through which institutions affect growth (Aron, 2000), with good institutions improving the efficiency of investment, and such variables might present some degree of collinearity with the institutional variable.

\subsection{Period of potential GDPpc growth}

Besides the 15-year average, the model is tested for three different periods of potential GDP for 3, 5 and 10 years. The interpretation of the estimate results is the same for the different models since the same explanatory variables are used. Notwithstanding, as the dependent variable changes across the different models, a direct comparison between the four models is impossible, but conclusions can be drawn. We will look for the magnitude of impact of each variable and verify how it changes for different growth periods.

The results are presented in Table 6.

Using different year averages of potential GDPpc growth, we wanted to verify whether the explanatory power of the variables was independent of time and, hence, test whether the medium run could also be used when studying the impact of such variables on economic growth.

Results allow us to verify that, independently of the growth time span selected, all the variables, except $R D$ and $I N F$, are significant. Besides keeping their significance, all the variables keep their sign, following economic growth theory. Whether we are analysing the medium or long run, the final model keeps its relevance in explaining economic growth.

We can also state some regularities across all growth span models concerning the magnitude of impact of each variable on economic growth. The estimated variable $\ln (G D P p c)$ has a bigger impact on potential growth than other explanatory variables, c.p. Hence, for each model considered, the catching-up effect seems to explain most potential GDPpc growth. Convergence in outcomes is more likely if institutional structures are similar, with countries narrowing the differences between them, and thus convergence is more likely to occur if such conditions are present. The big impact of catching-up on our results can translate into a requirement for a similar institutional framework across OECD countries. Convergence leads to similar long-run performances and more similar 
Table 6: Estimation results for baseline and final models with different growth spans for potential GDP

\begin{tabular}{|c|c|c|c|c|c|c|c|c|c|c|c|c|}
\hline \multirow{4}{*}{ Explanatory variables } & \multicolumn{12}{|c|}{ Potential GDP per capita growth $[1995,2006]$} \\
\hline & \multicolumn{3}{|c|}{ 3-year } & \multicolumn{3}{|c|}{ 5-year } & \multicolumn{3}{|c|}{ 10-year } & \multicolumn{3}{|c|}{ 15-year } \\
\hline & \multirow{2}{*}{$\begin{array}{l}\text { Pooled } \\
\text { OLS }\end{array}$} & \multicolumn{2}{|c|}{$\begin{array}{l}\text { Country and period } \\
\text { fixed-effects }\end{array}$} & \multirow{2}{*}{$\begin{array}{l}\text { Pooled } \\
\text { OLS }\end{array}$} & \multicolumn{2}{|c|}{$\begin{array}{l}\text { Country and period } \\
\text { fixed-effects }\end{array}$} & \multirow{2}{*}{$\begin{array}{l}\text { Pooled } \\
\text { OLS }\end{array}$} & \multicolumn{2}{|c|}{$\begin{array}{l}\text { Country and period } \\
\text { fixed-effects }\end{array}$} & \multirow{2}{*}{$\begin{array}{l}\text { Pooled } \\
\text { OLS }\end{array}$} & \multicolumn{2}{|c|}{$\begin{array}{l}\text { Country and period } \\
\text { fixed-effects }\end{array}$} \\
\hline & & Baseline & Final & & Baseline & Final & & Baseline & Final & & Baseline & Final \\
\hline $\ln (G D P p c)$ & $\begin{array}{l}-9.6509^{* * *} \\
(1.869)\end{array}$ & $\begin{array}{l}-87.2165^{* * *} \\
(29.490)\end{array}$ & $\begin{array}{l}-99.0189 * * * \\
(25.458)\end{array}$ & $\begin{array}{c}-7.3688^{* * *} \\
(1.057)\end{array}$ & $\begin{array}{c}-42.3171^{* * *} \\
(12.963)\end{array}$ & $\begin{array}{c}-47.2129 * * * \\
(11.652)\end{array}$ & $\begin{array}{l}-3.7982^{* * *} \\
(0.304)\end{array}$ & $\begin{array}{c}-23.7049 * * * \\
(8.243)\end{array}$ & $\begin{array}{c}-22.3746^{* * * *} \\
(0.076)\end{array}$ & $\begin{array}{c}-2.7894^{* * *} \\
(0.180)\end{array}$ & $\begin{array}{l}-20.5595^{* * *} \\
(5.568)\end{array}$ & $\begin{array}{l}-18.2062^{* * *} \\
(5.325)\end{array}$ \\
\hline Institutions & $\begin{array}{l}3.8780^{* * *} \\
(1.358)\end{array}$ & $\begin{array}{l}52.9263 * * * \\
(20.114)\end{array}$ & $\begin{array}{l}68.7503 * * * \\
(18.758)\end{array}$ & $\begin{array}{l}2.9186^{* * *} \\
(0.792)\end{array}$ & $\begin{array}{l}20.2593 * * \\
(8.930)\end{array}$ & $\begin{array}{l}27.6423^{* * * *} \\
(8.135)\end{array}$ & $\begin{array}{l}0.8236^{* * *} \\
(0.259)\end{array}$ & $\begin{array}{l}14.4922^{*} \\
(8.217)\end{array}$ & $\begin{array}{l}14.9512^{*} \\
(7.832)\end{array}$ & $\begin{array}{l}0.6080^{* * *} \\
(0.171)\end{array}$ & $\begin{array}{l}16.8572 * * * \\
(0.056)\end{array}$ & $\begin{array}{l}16.2291 * * * \\
(5.332)\end{array}$ \\
\hline Debtover60 & $\begin{array}{l}-1.1137 \\
(1.864)\end{array}$ & $\begin{array}{c}-5.0919^{*} \\
(2.993)\end{array}$ & $\begin{array}{c}-10.4173^{* * *} \\
(3.210)\end{array}$ & $\begin{array}{c}-1.4092 \\
(1.095)\end{array}$ & $\begin{array}{c}-2.0332 \\
(1.338)\end{array}$ & $\begin{array}{c}-4.5109 * * * \\
(1.446)\end{array}$ & $\begin{array}{c}-1.3834^{* * *} \\
(0.296)\end{array}$ & $\begin{array}{c}-1.3000 \\
(0.878)\end{array}$ & $\begin{array}{c}-1.6963^{*} \\
(0.945)\end{array}$ & $\begin{array}{l}-0.9677^{* * *} \\
(0.225)\end{array}$ & $\begin{array}{c}-1.4532^{* *} \\
(0.586)\end{array}$ & $\begin{array}{l}-1.5556^{* *} \\
(0.614)\end{array}$ \\
\hline Institutions $\widehat{\times D e b t o v e r} 60$ & $\begin{array}{l}1.1013 \\
(1.420)\end{array}$ & $\begin{array}{l}1.6897 \\
(1.678)\end{array}$ & $\begin{array}{l}6.1228^{* * *} \\
(2.273)\end{array}$ & $\begin{array}{l}1.0225 \\
(0.820)\end{array}$ & $\begin{array}{l}0.7739 \\
(0.765)\end{array}$ & $\begin{array}{l}2.7049 * * \\
(1.035)\end{array}$ & $\begin{array}{l}0.8411 * * * \\
(0.188)\end{array}$ & $\begin{array}{l}0.4675 \\
(0.420)\end{array}$ & $\begin{array}{l}0.9046^{*} \\
(0.523)\end{array}$ & $\begin{array}{l}0.5478^{* * *} \\
(0.150)\end{array}$ & $\begin{array}{l}0.5166^{* *} \\
(0.255)\end{array}$ & $\begin{array}{l}0.6525^{* *} \\
(0.311)\end{array}$ \\
\hline $\ln (G E E D U)$ & $\begin{array}{l}8.6972^{* * *} \\
(2.928)\end{array}$ & - & $\begin{array}{l}19.0463^{* * *} \\
(6.787)\end{array}$ & $\begin{array}{l}3.9870^{* * *} \\
(1.281)\end{array}$ & - & $\begin{array}{l}9.8263^{* * *} \\
(3.180)\end{array}$ & $\begin{array}{l}1.4184^{* * *} \\
(0.216)\end{array}$ & - & $\begin{array}{l}4.0562^{* * *} \\
(1.323)\end{array}$ & $\begin{array}{l}1.3067^{* * *} \\
(0.104)\end{array}$ & - & $\begin{array}{l}2.2272^{* * *} \\
(0.800)\end{array}$ \\
\hline $\ln (T r)$ & $\begin{array}{l}3.3796^{* * *} \\
(1.011)\end{array}$ & - & $\begin{array}{l}37.6640^{* * *} \\
(8.709)\end{array}$ & $\begin{array}{l}2.0072^{* * *} \\
(0.521)\end{array}$ & - & $\begin{array}{l}15.5356^{* * *} \\
(3.695)\end{array}$ & $\begin{array}{l}1.1067^{* * *} \\
(0.088)\end{array}$ & - & $\begin{array}{l}4.8704^{* * *} \\
(1.604)\end{array}$ & $\begin{array}{l}1.1467^{* * *} \\
(0.047)\end{array}$ & - & $\begin{array}{l}2.8390^{* * *} \\
(0.873)\end{array}$ \\
\hline $\ln (G E X P)$ & $\begin{array}{l}2.8454 \\
(2.680)\end{array}$ & - & $\begin{array}{l}39.0728^{* * *} \\
(12.114)\end{array}$ & $\begin{array}{l}1.3844 \\
(1.167)\end{array}$ & - & $\begin{array}{l}15.8235^{* * *} \\
(5.039)\end{array}$ & $\begin{array}{l}-0.4042^{* *} \\
(0.200)\end{array}$ & - & $\begin{array}{l}8.5506^{* * *} \\
(1.912)\end{array}$ & $\begin{array}{c}-0.0103 \\
(0.183)\end{array}$ & - & $\begin{array}{l}5.3745^{* * *} \\
(1.209)\end{array}$ \\
\hline GCF & $\begin{array}{c}-0.0735 \\
(0.189)\end{array}$ & - & $\begin{array}{l}0.4804^{*} \\
(0.255)\end{array}$ & $\begin{array}{c}-0.0667 \\
(0.084)\end{array}$ & - & $\begin{array}{l}0.1649 \\
(0.109)\end{array}$ & $\begin{array}{c}-0.0087 \\
(0.008)\end{array}$ & - & $\begin{array}{l}0.0802^{*} \\
(0.048)\end{array}$ & $\begin{array}{c}-0.0039 \\
(0.005)\end{array}$ & - & $\begin{array}{l}0.0220 \\
(0.027)\end{array}$ \\
\hline$R D$ & $\begin{array}{c}-1.0437^{* * *} \\
(0.003)\end{array}$ & - & $\begin{array}{l}0.8874 \\
(3.076)\end{array}$ & $\begin{array}{c}-0.6016^{* * *} \\
(0.152) \\
\end{array}$ & - & $\begin{array}{l}0.5250 \\
(1.323) \\
\end{array}$ & $\begin{array}{c}-0.0398 \\
(0.028) \\
\end{array}$ & - & $\begin{array}{l}0.4548 \\
(0.499) \\
\end{array}$ & $\begin{array}{c}-0.0912^{* * *} \\
(0.027) \\
\end{array}$ & - & $\begin{array}{l}0.0952 \\
(0.268)\end{array}$ \\
\hline INF & $\begin{array}{c}-0.0169 \\
(0.244) \\
\end{array}$ & - & $\begin{array}{l}0.4211 \\
(0.257)\end{array}$ & $\begin{array}{c}-0.0562 \\
(0.121) \\
\end{array}$ & - & $\begin{array}{l}0.1273 \\
(0.116)\end{array}$ & $\begin{array}{l}0.0177 \\
(0.012)\end{array}$ & - & $\begin{array}{l}0.0660 \\
(0.046)\end{array}$ & $\begin{array}{l}0.0142 \\
(0.009)\end{array}$ & - & $\begin{array}{l}0.0380 \\
(0.027)\end{array}$ \\
\hline Sample size & 178 & 178 & 178 & 178 & 178 & 178 & 178 & 178 & 178 & 178 & 178 & 178 \\
\hline Adjusted R-squared & 0.2433 & 0.3283 & 0.4928 & 0.4212 & 0.5273 & 0.6367 & 0.9662 & 0.7201 & 0.7783 & 0.9538 & 0.8311 & 0.8700 \\
\hline Wald F-statistic & $\begin{array}{c}54.8981 \\
(0.000) \\
\end{array}$ & $\begin{array}{c}101.9453 \\
(0.000)\end{array}$ & $\begin{array}{l}61.2786 \\
(0.000) \\
\end{array}$ & $\begin{array}{c}117.9938 \\
(0.000)\end{array}$ & $\begin{array}{c}305.3437 \\
(0.000)\end{array}$ & $\begin{array}{c}171.7072 \\
(0.000)\end{array}$ & $\begin{array}{c}130.9589 \\
(0.000)\end{array}$ & $\begin{array}{c}883.1219 \\
(0.000)\end{array}$ & $\begin{array}{c}564.4848 \\
(0.000)\end{array}$ & $\begin{array}{c}1840.302 \\
(0.000)\end{array}$ & $\begin{array}{c}2160.614 \\
(0.000)\end{array}$ & $\begin{array}{c}1371.901 \\
(0.000) \\
\end{array}$ \\
\hline $\begin{array}{l}\text { F-test (country and } \\
\text { period effects) }\end{array}$ & - & $\begin{array}{l}1.9354 \\
(0.000) \\
\end{array}$ & $\begin{array}{l}3.3478 \\
(0.000)\end{array}$ & - & $\begin{array}{l}2.6211 \\
(0.000) \\
\end{array}$ & $\begin{array}{l}3.8092 \\
(0.000) \\
\end{array}$ & - & $\begin{array}{l}3.9440 \\
(0.000)\end{array}$ & $\begin{array}{l}4.7249 \\
(0.000) \\
\end{array}$ & - & $\begin{array}{l}8.1714 \\
(0.000)\end{array}$ & $\begin{array}{l}6.9769 \\
(0.000) \\
\end{array}$ \\
\hline $\begin{array}{l}\text { F-statist. (redundant } \\
\text { variables) }\end{array}$ & - & - & $\begin{array}{l}4.5356 \\
(0.000)\end{array}$ & - & - & $\begin{array}{l}6.0940 \\
(0.000)\end{array}$ & - & - & $\begin{array}{l}6.2945 \\
(0.000)\end{array}$ & - & - & $\begin{array}{l}6.1603 \\
(0.000)\end{array}$ \\
\hline
\end{tabular}

Note: See Table 3.

Source: Own calculations 
structural conditions (Marelli and Signorelli, 2010). As our estimation results show, there is convergence, and OECD countries show similar institutional quality.

The magnitude of the estimate of Institutions is the second biggest among the explanatory variables. Hence, institutions appear to be crucial in explaining economic growth, in both medium and long run. Moreover, since we are using WGI indicators that measure the quality of administrative and economic institutions rather than political ones, economic institutions are determinant in explaining medium and long-run growth for developed countries. Economic institutions are particularly relevant since they create incentives for society, encouraging individuals to innovate, accumulate and control their economic returns (Das and Quirk, 2016). Hence, development of such institutions' stimulates economic agents to participate in the marketplace and create economic value.

The debt dummy variable has the sixth-highest impact on potential economic growth across all growth periods. Therefore, other variables can be taken as more influential in explaining economic growth for the medium and long run.

Among the structural variables, $\ln (G E X P)$ and $\ln (T r)$ are the most considerable. The variable $\ln (G E E D U)$ is of less relevance for explaining growth.

\section{Conclusion}

The impact of institutions on economic growth has been studied mainly for developing countries, where institutional quality needs improvement. There is insufficient knowledge about the importance of institutions in developed countries, particularly in terms of the effect on economic growth. In the OECD, where institutional quality is relatively good, one might ask how much economic growth is due to institutions.

WGIs have been used to measure institutional quality. Due to the obstacles that the study of institutions implies, one of them being endogeneity, we looked for ways to deal with such issues by (i) measuring institutions at the beginning of the period; and (ii) using the estimation method with instrumental variables. Using panel data, we estimated two models: a base model, which includes the initial level of GDP per capita, the institutional variable, a dummy variable of the debt and the interaction between these last two variables; then we extended the base model with structural variables commonly used in the economic literature and obtained the final model, which tries to explain more fully the sources of economic growth. As a robustness exercise, we applied different periods for the GDP growth variable, namely 3, 5, 10 and 15 years.

The results showed us the positive impact of institutions on medium and long-run economic growth in the case of OECD countries. The importance of institutions is not limited in itself: in the presence of high debt, good institutions can alleviate the negative impact of debt on economic growth, cushioning its harmful effect on production. 
This result is relevant for countries with high levels of debt, which should thus improve their institutional quality. This interaction effect can be considered one of several channels through which institutions affect growth indirectly, investment being another.

The added structural variables improved the model suitability and were significant over different periods, showing signs according to the economic literature. Institutions stand out among the variables with the greatest impact. Thus, for developed countries, institutions are a robust variable in explaining potential GDPpc.

The use of different types of institutions, namely policies, could help to find the most relevant type for economic growth in developed countries, which is left for future research. In any case, we consider that this paper contributes to the existing literature by increasing the knowledge of institutions regarding their definition, categorization and measurement and how they affect economic growth in developed countries.

\section{References}

Acemoglu, D., Robinson, J. (2010). The Role of Institutions in Growth and Development. Leadership and Growth, 135.

Acemoglu, D., Johnson, S., Robinson, J. A. (2004). Institutions as the Fundamental Cause of Long-run Growth. National Bureau of Economic Research. Cambridge, MA Working Paper No. 10481, https://doi.org/10.3386/w10481

Ali, A. M. (2003). Institutional Differences as Sources of Growth Differences. Atlantic Economic Journal, 31(4), 348-362, https://doi.org/10.1007/bf02298493

Alonso, J. A. (2011). Colonization, Institutions and Development: New Evidence. Journal of Development Studies, 47(7), 937-958, https://doi.org/10.1080/00220388.2010.527948

Apaza, C. R. (2009). Measuring Governance and Corruption Through the Worldwide Governance Indicators: Critiques, Responses, and Ongoing Scholarly Discussion. PS: Political Science and Politics, 42(1), 139-143, https://doi.org/10.1017/s1049096509090106

Aron, J. (2000). Growth and Institutions: A Review of the Evidence. World Bank Research Observer, 15(1), 99-135, https://doi.org/10.1093/wbro/15.1.99

Barro, R. J. (1996). Determinants of Economic Growth: A Cross-country Empirical Study. National Bureau of Economic Research. Cambridge, MA Working Paper No. 5698, https://doi.org/10.3386/w5698

Bassanini, A., Scarpetta, S., Hemmings, P. (2001). Economic Growth: The Role of Policies and Institutions. Panel Data Evidence from OECD Countries. OECD Economics Department. Paris Working Papers No. 283, https://doi.org/10.2139/ssrn.265091

Bouis, R., Duval, R., Murtin, F. (2011). The Policy and Institutional Drivers of Economic Growth across OECD and non-OECD Economies: New Evidence from Growth Regressions.

OECD Economics Department. Paris Working Papers No. 843, https://doi.org/10.1787/5kghwnhxwkhj-en 
Chalaux, T., Guillemette, Y. (2019). The OECD Potential Output Estimation Methodology.

OECD Economics Department. Paris Working Papers No. 1563,

https://doi.org/10.1787/4357c723-en

Chalk, N., Tanzi, V. (2002). Impact of Large Public Debt on Growth in the EU, in Buti, M., ed., Behaviour of Fiscal Authorities: Stabilization, Growth and Institutions. Basingstoke: Palgrave, pp. 186-211. ISBN 0-333-98495-1.

Das, K., Quirk, T. (2016). Which Institutions Promote Growth? Revisiting the Evidence. Economic Papers, 35(1), 37-58, https://doi.org/10.1111/1759-3441.12128

Eicher, T. S., Leukert, A. (2009). Institutions and Economic Performance: Endogeneity and Parameter Heterogeneity. Journal of Money, Credit and Banking, 41(1), 197-219, https://doi.org/10.1111/j.1538-4616.2008.00193.x

Eicher, T., Röhn, O. (2007). Institutional Determinants of Economic Performance in OECD Countries - An Institutions Climate Index. CESifo DICE Report, 5(1), 38-49.

European Central Bank (2011). Monthly Bulletin January: Trends in Potential Output. Frankfurt am Main: European Central Bank, pp. 73-79.

Égert, B. (2013). The 90\% Public Debt Threshold: The Rise and Fall of a Stylized Fact. OECD Economics Department. Paris Working Papers No. 1055, https://doi.org/10.1787/5k452kln1s6l-en

Freeman, R. B. (2002). Institutional Differences and Economic Performance among OECD Countries. Centre for Economic Performance, London School of Economics and Political Science. London Working Papers No. 557.

Fuentelsaz, L., González, C., Maicas, J. P. (2019). Formal Institutions and Opportunity Entrepreneurship. The Contingent Role of Informal Institutions. BRQ Business Research Quarterly, 22(1), 5-24, https://doi.org/10.1016/j.brq.2018.06.002

Glaeser, E. L., Porta, R. L., Lopez-de-Silanes, F., et al. (2004). Do Institutions Cause Growth? Journal of Economic Growth, 9(3), 271-303, https://doi.org/10.1023/b:joeg.0000038933.16398.ed

Helliwell, J. F., Huang, H., Grover, S., et al. (2014). Good Governance and National Well-being. What Are the Linkages? OECD. Paris Working Papers on Public Governance No. 25, https://doi.org/10.1787/5jxv9f651hvj-en

Kraay, A., Kaufmann, D., Mastruzzi, M. (2010). The Worldwide Governance Indicators: Methodology and Analytical Issues. Washington, D.C.: The World Bank, https://doi. org/10.1596/1813-9450-5430

Kuncic, A. (2012). Institutional Quality Database. Kiel Institute for the World Economy (IfW). Kiel Working Papers No. 457.

Marelli, E., Signorelli, M. (2010). Institutional, Nominal and Real Convergence in Europe. Banks \& Bank Systems, 5(2), 140-155.

Masuch, K., Moshammer, E., Pierluigi, B. (2016). Institutions and Growth in Europe. Centre for European Policy Studies (CEPS). Brussels Working Document No. 421.

Mencinger, J., Aristovnik, A., Verbic, M. (2015). Revisiting the Role of Public Debt in Economic Growth: The Case of OECD Countries. Engineering Economics, 26(1), 61-66, https://doi.org/10.5755/j01.ee.26.1.4551 
North, D. C. (1991). Institutions. Journal of Economic Perspectives, 5(1), 97-112, https://doi. org/10.1257/jep.5.1.97

Nugroho, H., Pasay, N. H. A., Damayanti, A., et al. (2019). Institutions as the Main Determinant in Economic Growth. Etikonomi, 18(1), 13-28, https://doi.org/10.15408/etk.v18i1.8242

OECD (2003). Policy Settings, Institutions and Aggregate Economic Growth: A Cross-Country Analysis. In: The Sources of Economic Growth in OECD Countries, pp. 55-89. Paris: OECD Publishing, Paris, https://doi.org/10.1787/9789264199460-4-en

Pain, N., Koske, I., Sollie, M. (2008). Globalization and OECD Consumer Price Inflation. OECD Journal: Economic Studies, 2008(1), 1-32, https://doi.org/10.1787/ eco_studies-v2008-art4-en

Panizza, U., Presbitero, A. F. (2013). Public Debt and Economic Growth in Advanced Economies: A Survey. Swiss Journal of Economics and Statistics, 149(2), 175-204, https://doi.org/10.1007/bf03399388

Pasimeni, F., Pasimeni, P. (2016). An Institutional Analysis of the Europe 2020 Strategy. Social Indicators Research, 127(3), 1021-1038, https://doi.org/10.1007/s11205-015-1013-7

Porta, R. L., Lopez-de-Silanes, F., Shleifer, A., et al. (1999). The Quality of Government. Journal of Law, Economics, and Organization, 15(1), 222-279, https://doi.org/10.1093/ jleo/15.1.222

Rodrik, D. (2003). Institutions, Integration, and Geography: In Search of the Deep Determinants of Economic Growth. In Search of Prosperity: Analytic Country Studies on Growth. Princeton, NJ: Princeton University Press.

Rodrik, D. (2004). Institutions and Economic Performance-getting Institutions Right. CESifo DICE Report, 2(2), 10-15.

Singh, T. (2010). Does International Trade Cause Economic Growth? A Survey. World Economy, 33(11), 1517-1564, https://doi.org/10.1111/j.1467-9701.2010.01243.x

Solow, R. M. (1956). A Contribution to the Theory of Economic Growth. Quarterly Journal of Economics, 70(1), 65-94, https://doi.org/10.2307/1884513

Thomas, M. A. (2010). What Do the Worldwide Governance Indicators Measure? European Journal of Development Research, 22(1), 31-54, https://doi.org/10.1057/ejdr.2009.32

Tornell, A., Lane, P. R. (1999). The Voracity Effect. American Economic Review, 89(1), 22-46, https://doi.org/10.1257/aer.89.1.22

Valeriani, E., Peluso, S. (2011). The Impact of Institutional Quality on Economic Growth and Development: An Empirical Study. Journal of Knowledge Management, Economics and Information Technology, 1(6), 1-25.

Vanston, N. (2006). Summary of a Workshop on Global Convergence Scenarios: Structural and Policy Issues. OECD Economics Department. Paris Working Papers No. 483, https://doi.org/10.1787/848377031632

World Bank Group (2018). Building Solid Foundations: How to Promote Potential Growth. Global Economic Prospects, 159-205, https://doi.org/10.1596/978-1-4648-1163-0_ch3 